\title{
The Significance of Strategic Control on the Growth of Churches in Harare, Zimbabwe
}

\author{
Frank Chikhata* Edgar Makande Alex Benjamin Madzivire \\ Women's University in Africa, Harare, Zimbabwe
}

\begin{abstract}
The research aimed to assess the effect of strategic control on the growth of churches in Harare, Zimbabwe. The research looked at the influence of strategic control on the growth on both Mainline and Pentecostal churches. The study followed a positivism philosophy, where an explanatory research design was applied. A multi-stage stratified random sampling was used to select the study participants who were adult congregants and church leaders from two strata, one stratum being made up of mainline churches and the other one by Pentecostal churches. Multi-stage stratified random sampling was deemed appropriate for the research as it ensured that there was representativeness within and across the strata. Data was collected from systematically selected congregants and church leaders in selected churches through interviewer-administered questionnaires using Open Datakit, a mobile data collection platform. Data analysis revealed that there was evidence of implementation of strategic control (mean score of 4) as part of strategic management practices in both Mainline and Pentecostal churches. Additionally, the findings show that strategic control influences the growth of churches ( $p$-value $<0.001$ ). These findings showed that churches like any other organizations can be affected by the change in the socio-economic environment and thus they should implement appropriate strategies to remain viable and relevant. Strategic control plays a crucial role in ensuring that those strategies are effectively implemented. An effective Strategic Management Framework should be formulated and guide how churches can continuously control the implementation of their strategies to remain viable and achieve their mandate.
\end{abstract}

Keywords: strategic control, church, church growth, strategic management

DOI: $10.7176 / \mathrm{EJBM} / 12-32-06$

Publication date: November $30^{\text {th }} 2020$

\section{Introduction and Background of the Study}

Strategic control as part of strategic management practices is fundamental in ensuring that organizations enhance strategic implementation. Strategic Management control systems are believed to be tools that can be used to clarify strategies and objectives defined to deliver value by facilitating strategy implementation and by enhancing organizational performance in today's competitive environment (Ittner \& Larcker, 2003; Widener, 2007).

It is generally acknowledged in business practice that, controlling the implementation of strategies is crucial to enhance the effective performance of the corporate competitive strategy (Toit, 2005; Albright, 2004; and Wheelen and Hunger, 2003). To be successful, organizations should be conscious of how effective their systems interact with the environment. Hambrick (1982), Cheng (2014) and Toit, (2005) defined the environment as anything found outside the boundaries of an organization, or sets of elements that are independent of the organization and are of importance for its success. In essence, organizations are creatures of their surrounding environments, spending much time to learn how to deal with the traumas and opportunities created by that environment (Douglas, 1994). Strategic control cannot be isolated from what is happening in the operating environment. Churches, just like other organizations, operate and interact with an environment. That environment can affect their growth, both physically and spiritually.

Despite the embracing of strategic control as part of strategic management in the private and public sector, there is little evidence to suggest the adoption of the same concept in churches. Churches, like any organization, can be affected by the operating business environment and thus the effective implementation of strategic control measures could enhance the achievement of their objectives and mandate.

Globally, according to Shah, David, \& Surawski (2003), protestant churches lost between one-fifth and onethird of their membership between 1965 and 1990. Additionally, Malphurs (2004) argued that in 1988 between $80 \%$ and $85 \%$ of churches in North America were either plateaued or were declining. However, both studies did not articulate what could have caused the plateau or decline. A similar study in 2013, postulated that there had not been any change in the status of those churches despite a huge surge in church establishment (Malphurs, 2013). There has been a study in 2014 that postulated a steady decline in the percentage of Christians in the United States (US) (A Religious Landscape Study, 2014). The study showed that adult Christian affiliation decreased from $78.4 \%$ in 2007 to $70.6 \%$ in 2014. Similarly, in Zimbabwe, there has been a $4 \%$ decrease in the percentage of Christians attending mainline and Pentecostal churches from 2005 to 2015 (Zimbabwe National Statistics Agency and ICF International, 2016; Central Statistical Office (CSO) [Zimbabwe] and Macro International Inc., 2007). Shah, David, \& Surawski (2003) suggested that formal planning and strategic 
implementation could improve growth rates of these churches. Controlling the implementation of such strategies could be crucial in improving the growth of such churches. However, not much evidence has been brought forward to confirm that. The current study addressed this.

\section{Research objectives}

The main objective of the study was to establish the effect of strategic control on Church growth in Harare, Zimbabwe.

\section{Literature Review}

\subsection{Strategic Control}

The purpose of a control system is to make sure that business strategies meet predetermined goals and objectives (Lorange, Morton, and Ghoshal, 1986). To evaluate and control a strategy (Rossouw et al. 2003:226) involves the monitoring of the strategy as it is being implemented and making necessary adjustments to any deviations.

There has been an agreement among most Strategists that strategic control is crucial for an organisation's viability (David, 2015). As postulated by David, 2015, strategy evaluation comprises of three basic activities: (1) assessing the underlying bases of a firm's strategy, (2) comparing anticipated results with actual results, and (3) taking corrective actions to ensure that performance conforms to the set plans.

In many organisations, strategy evaluation is simply an appraisal of how well an organisation has performed For instance, when evaluating strategy implementation the organisations have to consider the following: whether there has been an increase in the organisation's assets; profitability and sales. For churches, the following could be considered, whether there has been an increase in church assets, membership, social ministries among others.

\subsection{Strategic Control and Business Performance}

Strydon (2011) articulated that strategy evaluation and control notifies the managers about the reason why there is a failure to meet certain objectives, performance standards or any other performance indicators. To achieve this, the author suggests five tasks that must be performed. The first task is to constantly revise and update the plan so that it suits the environmental conditions. The second task is to set up standards that need to be met to achieve the goals. Thirdly, management must evaluate the performance of employees through performance appraisals to ascertain if everyone is performing as required. The fourth task is to prevent problems and crises through proactive planning. Finally, evaluation and control protect the business from collapse as it ensures that errors are attended to and addressed timely.

Pearce and Robinson (2005:366) agree that strategic control and evaluation is concerned with guiding action during and after strategy implementation. Additionally, they draw attention to the fact that in strategy review and control, managers are concerned with two key issues. First, they ask themselves if the organisation is moving in the proper direction if all activities are being implemented according to plan if the assumptions that were made about major trends and changes in the environment are accurate if there are shortcomings that need to be adjusted, and if there is need to continue with the strategy or quit it. Secondly, the organisations need to evaluate how they are performing as far as meeting the objectives and targets is concerned. It is also crucial to measure progress to ascertain whether or not the schedules, costs, revenues and cash flows are matching the projections, and if there is need to make operational alterations.

Rossouw et al. (2003) stressed four preconditions that need to be met for the successful monitoring, evaluation and control of a strategy. First, the business' goals and objectives must be measurable and adequate to permit easy measurement of progress. Secondly, if there are deviations, it should be possible for an organisation to establish the reasons for such deviances. Thirdly, there should be communication links or systems in place to enhance feedback links for managers to respond when variances happen. Lastly, the information about the progress in achievements of objectives should be appropriate and adequate for managers to make informed decisions.

Four criteria can be used to evaluate strategies as postulated by David (2003:302). These are consistency, consonance, feasibility and advantage. Inconsistencies in the success of a strategy occur if one department succeeds and one fails, and if policy problems still occur and are brought to top management for determination. Consonance focuses on the organisation's capacity to align its strategies to its strategic internal and external environments. While the feasibility of the strategy refers to the examination of the business' abilities, competencies, skills and talents required to execute a given strategy, an advantage of a strategy involves its ability to create superiority in the way it utilises its resources, skills, as well as its competitive position in the market (David 2003:302). Consonance and advantage are mostly grounded on an organisation's external assessment, whereas consistency and feasibility are fundamentally based on an internal assessment (David 2011: 288).

Rossouw et al. (2003) postulated that strategy control takes place at three levels, namely the strategic level, 
the functional level and the operational level. Whereas the strategic control guides the business over long periods, the tactical and operational control levels offer post-action review and control over short periods (Rossouw et al., 2003). Pearce and Robinson (2005:366) indicate that strategic control is crucial as it guides the business to make sure that correct things are implemented and adjustments are made to correct any problems. Changes in the business' internal and external environments require the need for the business to make changes continually so that the business is not adversely affected by such fluctuations (Rossouw et al., 2003). The current researcher sought to see whether this can apply to churches and what could be the effect on the growth of such churches.

David (2003:303) argues that a continuous rather than periodic strategy evaluation is necessary for all businesses, regardless of size, sector or industry affiliation. The reason is that a continuous evaluation of strategies offers benefits such as allowing benchmarking of progress to be established and monitored effectively, creating manager and employee commitment to achieve objectives, and enabling the monitoring of changes in the external opportunities and threats as well as internal strengths and weaknesses of the business. In that vein, David (2003:306) suggests a strategy evaluation framework that can be used to continuously evaluate its progress.

If the implementation of a chosen strategy is according to set standards, the strategy proceeds whilst being monitored continuously, but whenever there are deviations of performance from the expected standard, corrective actions need to be taken. In David's (2003:308) opinion, evaluating and controlling performance continually helps the business to maintain a balance between the chosen strategies and the objectives to be achieved. This indicates that a continual evaluation of business performance ensures continuous improvements, as it can adjust to the needs of a changing environment. This could be true of churches in terms of continuous evaluation of their operations and performance to achieve their mandate.

\subsection{Church Growth}

There is uniqueness in churches as an organizational eternity. However, just like any organization, growth is an important measure of organizational success. For churches, the growth can be both physical and spiritual. For this research, the physical growth is measured by expansion in the church's infrastructure, numerical increase in church membership, expansion of the church's social ministries and increase in the church's financial resources. Additionally, the spiritual growth is measured by a four-category framework looking at; the interconnectedness of humanity scale, spiritual identification scale, relationship with God scale, and living one's philosophy of life with integrity scale.

Researchers classified physical church growth into three sources including organic, conversion or transfer growth (Davis et al., 2010; Rainer, 1993). Organic growth happens when children of current members become members in their own desire. Conversion growth arises when a church entices from the "community and win people to Christ" (Davis et al., 2010). Transfer growth was described as existing church congregants who "transfer to a new church" (Davis et al., 2010). Rainer (1993) described transfer growth as progression "at the expense of another church". Hong (2004) used four categories for church growth, including (a) internal, (b) expansion, (c) extension (church planting), and (d) bridging (church planting in different cultures) growth. Hong combined biological, transfer, and conversion progression for his expansion growth type. For this study, the physical growth was not defined by the source. The physical growth and spiritual growth were Dependent variables (DV).

\section{Research Methodology}

The researchers used an explanatory research design. The main focus of explanatory research is to identify any causal links between the factors or variables that pertain to the research problem. This was the focus of this research study, hence the design was considered relevant. The explanatory research design was chosen for this study because it helped the researchers to gain insight into whether there are any relationships between strategic control and the growth of churches as measured by the increase in membership, infrastructure, social ministries, financial (physical growth) and Interconnectedness of Humanity, Spiritual Identification, Relationship with God and Living with integrity (spiritual growth). The population for this study comprised congregants and pastors from both mainline and Pentecostal churches in Harare. Multi-stage stratified random sampling technique was used to draw 384 congregants, including pastors, from the total population. The data was collected using a structured questionnaire with a five-point Likert scale administered by Research Assistants using on Open Data Kit (ODK), a mobile data collection platform. The response rate was $100 \%$. Data analysis was done using SPSS version 23.

\section{Results/findings}

This section presents an analysis of the data collected and the results from the research. Besides, interpretation and presentation of the findings in line with the research objectives are expounded. 


\subsection{Assessing Normality}

The assumption of normality, normal distribution, is a prerequisite for many inferential statistical techniques. A normal distribution can be defined as a symmetric bell-shaped curve, which is defined by the mean and the standard deviation. Violating such an assumption significantly may result in a type I or type II error being committed, based on the type of analysis conducted (Osborne, 2002). According to Coakes and Steed (2007: 31), there are several different ways to explore this assumption graphically. These include histograms, stem-and-leaf plots, boxplots, normal probability plots and de-trended normal plots. Furthermore, several statistics are available to test normality. These are mainly Kolmogorov-Smirnov statistic and the Shapiro Wilk statistic, skewness, and kurtosis. While the former procedure relies on visual inspection, the numerical procedure relies on statistical tests. Graphical procedures include histograms and stem leaf, whereas numerical procedures include inferential tests, such as the Kolmogorov-Smirnov (K-S) test and the Shapiro-Wilk (S-W) test. Such tests compare the normality of data to the normal distribution, which has the same mean and standard deviation as does the sample. The current study opted for carrying out the numerical tests because they offer the advantage of providing an objective assessment, rather than a visual inspection. The K-S test is considered suitable for samples larger than 2000, whereas the S-W test is deemed appropriate for samples ranging from 50 to 2000 . As the current study contained 384 responses, the S-W test was the appropriate test to use. As is the case with tests which are conducted on univariate outliers, it was considered practical to carry out the test of normality using composite variables. The results of the test, using SPSS, Version 23.0, are reported in Table 5.1.

Table 5.1: Results of the Shapiro-Wilk (S-W) test of normality of data

\begin{tabular}{lll}
\hline Composite variable & Shapiro-Wilk $(\mathbf{S}-\mathbf{W})$ test & \\
& Statistic & Significance \\
\hline Strategic control & .996 & .165 \\
Spiritual church growth & .992 & .150 \\
Physical church growth & .989 & .089 \\
Overall church growth & .994 & .164 \\
\hline
\end{tabular}

According to the S-K test, the null hypothesis (i.e. there is no difference between the distribution of the data set and the normal distribution) was tested. In keeping with convention, the alpha level was set at 0.05 . Such a hypothesis can only be rejected if the p-value from the test is less than 0.05 (meaning that it is significant). If such a value is greater than 0.05 (meaning that it is non-significant), the null hypothesis cannot be rejected. As Table 5.1 shows, the p-values for the composite variables were as follows: for strategic control 0.165; for spiritual church growth 0.150; for physical church growth 0.089 ; and overall church growth 0.164 . All such values were found to exceed 0.05 , which implies that the null hypothesis that states that there is no difference between the distribution of this data set and the normal distribution is not rejected. This implied that the dataset was normally distributed.

\subsection{Reliability Test}

The reliability test was conducted to test for internal consistency of the interviewer-administered questionnaire. Cronbach`s alpha test was used in this research study and the results are shown in Table 5.2.

Table 5.2: Reliability of Instrument and Concepts

\begin{tabular}{lccc}
\hline Variable & No. of Items & Cronbach's Alpha $(\boldsymbol{\alpha})$ & Decision \\
\hline Strategic control & 11 & 0.848 & Accept \\
Church growth(physical) & 15 & 0.805 & Accept \\
Church growth (spiritual) & 64 & 0.933 & Accept \\
\hline
\end{tabular}

As indicated in Table 5.2, Cronbach alpha coefficients are 0.848, 0.805 and 0.933 for strategic control, physical church growth and spiritual church respectively. According to George and Mallery (2003), a Cronbach Alpha score above 0.7 is regarded as acceptable for most research studies. For each variable as shown in table 4.3 , the assumptions of internal consistency were not violated, implying that the data was reliable as all the alpha values $>0.70$.

\subsection{Descriptive Statistics}

In the study, descriptive statistics were computed from the responses obtained to determine the means and standard deviations for the variables obtained in the study. As opined by Levin and Rubin (2000), such a technique facilitated the display and interpretation of data by describing the distribution of the study variables. Determining the frequency of a given phenomenon in a study requires the computation of the means or the average scores of data collected, as well as the variability scores of the responses on various items in the questionnaire, which are represented by the respective standard deviations. The study collected data obtained in response to the application of a 5-point Likert scale. 
Table 5.3: Mean scores and standard deviations of church growth variables

\begin{tabular}{lcc}
\hline Variable dimension & Mean Score & Std deviation \\
\hline Strategic Control & $\mathbf{4 . 0 1}$ & $\mathbf{0 . 6 4}$ \\
Spiritual Church growth & $\mathbf{3 . 9 6}$ & $\mathbf{0 . 3 9}$ \\
Interconnectedness of Humanity & 3.97 & 0.48 \\
Spiritual Identification & 4.22 & 0.33 \\
Relationship with God & 3.92 & 0.47 \\
Living with integrity & 3.71 & 0.64 \\
Physical Church growth & 3.53 & $\mathbf{0 . 4 3}$ \\
Growth in Church infrastructure & 3.31 & 0.69 \\
Increase in Church membership & 3.31 & 0.72 \\
Increase in Church Social Ministries & 3.64 & 0.61 \\
Increase in Financial Resources & 3.18 & 0.70
\end{tabular}

As highlighted in table 5.3, the mean score for the strategic control was 4.01 with a standard deviation of 0.64. Additionally, the mean scores for the spiritual church growth were higher than those of the physical church growth. A paired sample t-test was conducted and it was found that there was a significant difference between physical church growth and spiritual church growth (p-value $<0.001)$. The analysis of the spiritual growth by sex showed that there was no significant difference between men and women ( $\mathrm{p}$-value $=0.068$ ). The mean scores obtained for the church growth variables were found to range from 3.18 with a standard deviation of (the measure of dispersion) of 0.70 being the lowest for increase in financial resources to 4.22 being the highest mean, scored by spiritual identification with a standard deviation of 0.33 .

\subsection{Hypothesis Testing}

A simple linear regression analysis was conducted to test the hypotheses.

5.4.1 Hypothesis 1

$\mathrm{H}_{01}$ : Strategic control does not influence spiritual church growth Table 5.4: Strategic control ANOVA ${ }^{1}$

\begin{tabular}{lrrrrr}
\hline Model & Sum of Squares & df & Mean Square & F & p-value \\
\hline Regression & 12.122 & 1 & 12.122 & 98.608 & 0.000 \\
Residual & 46.469 & 378 & 0.123 & & \\
Total & 58.592 & 379 & & & \\
\hline
\end{tabular}

${ }^{1}$ Dependent Variable: spiritual church growth

Predictors: (Constant), Strategic control

The p-value from the ANOVA table (table 5.4) $<0.001$ is less than 0.05 ; as such we reject the null hypothesis. This implies that strategic control affects the spiritual growth of churches.

5.4.2 Hypothesis 2

$\mathrm{H}_{02}$ : Strategic control does not influence physical church growth

Table 5.5: Strategic control ANOVA ${ }^{2}$

\begin{tabular}{lrrrrr}
\hline Model & Sum of Squares & df & Mean Square & F & p-value \\
\hline Regression & 1.416 & 1 & 1.416 & 7.825 & 0.005 \\
Residual & 68.395 & 378 & 0.181 & & \\
Total & 69.810 & 379 & & & \\
\hline
\end{tabular}

2. Dependent Variable: physical church growth

Predictors: (Constant), strategic control

The p-value from the ANOVA table (table 5.5) is 0.005 which is less than 0.05 as such the null hypothesis is rejected. This implies that strategic control affects the physical church growth. 


\subsubsection{Hypothesis 3}

$\mathrm{H}_{03}$ : Strategic control does not influence overall church growth

Table 5.5: Strategic control ANOVA ${ }^{3}$

\begin{tabular}{lrrrrr}
\hline Model & Sum of Squares & df & Mean Square & F & p-value \\
\hline Regression & 5.456 & 1 & 5.456 & 49.677 & 0.000 \\
Residual & 41.516 & 378 & 0.110 & & \\
Total & 46.972 & 379 & & & \\
\hline
\end{tabular}

3. Dependent Variable: overall church growth

Predictors: (Constant), strategic control

The p-value from the ANOVA table (table 5.5) $<0.001$; this is less than 0.05 as such the null hypothesis is rejected. This implies that strategic control affects the overall church growth.

\section{Discussion}

The conducted research aimed to analyse the impact of strategic control on the growth of churches in Harare, Zimbabwe. The results show that strategic control affects both the physical and spiritual growth of churches. As asserted by Rossouw et al., (2003), and David (2003), strategic control is crucial for organisations as if done properly would enhance competitive advantage. Companies need to be vigilant to the changing context and ensure that proper mechanisms are put in place to enhance strategic management implementation. The truth can be said of churches as they are also organisations. The findings ensure that strategic controls are crucial for churches as organisations. Strategic control contributes to both physical and spiritual church growth, thus church leaders can benefit from implementing strategic control mechanisms as part of strategic management in their churches. Since there has not been enough literature to compare similar studies in churches, these findings are of paramount importance in strategic management implementation in churches. Additionally, the findings will add value to the existing body of knowledge.

\section{Conclusion and Implications}

This study concludes that strategic control was a significant factor concerning church growth in Harare, Zimbabwe. According to the study findings, strategic control had a moderate positive contribution to the performance of churches as measured by growth in Harare, Zimbabwe. The results from the correlation analysis and regression analysis indicated that strategic control as part of strategic management practices had a positive though a very moderate contribution to the overall growth of churches in Harare, Zimbabwe. These findings thus suggest that strategic church leaders should consider strategic control to enhance church performance in Harare, Zimbabwe. In this regard, it can be concluded that, for church leaders to improve the performance of their churches significantly they should engage in balanced strategic control, among other strategic management practices. On policy implications, the study of strategic management should be introduced to all bible schools so that the issues of management are incorporated in their training curriculum. This approach could instill the strategic management culture among the students, thus making them good managers when they graduate as pastors. This would ultimately enhance effective management of churches as social organisations.

\section{References}

Albright, K. S., 2004. Environmental Scanning: Radar for Organizational Success. Information Management Journal, $38-45$

Central Statistical Office (CSO) [Zimbabwe] and Macro International Inc., 2007. Zimbabwe Demographic and Health Survey 2005-06. Calverton, Maryland: CSO and Macro International Inc

Cheng. 2014. The Strategic Planning of SMEs in Malaysia. International Journal of Business and Society, 15(3), 437-446

David, S., 2015. Managing dualities in organizational change projects, Journal of Change Management, DOI: 10.1080/14697017.2015.1118142

Davis, J. L., Bell, R. G., \& Payne, G. T., 2010. Stale in the pulpit? Leader tenure and the relationship between market growth strategy and church performance. International Journal of Non-profit \& Voluntary Sector Marketing, 15(4), 352368.

Douglas, B., 1994. Organizing for Environmental Scanning: Orthocloxies and Reformations. Journal of Marketing Management, 10, 703-723

George, D. \& Mallery, P. 2003. Statistical Package for Social Science for windows step by step: A simple guide and reference. $4^{\text {th }}$ ed. Boston: Allyn and Bacon

Hong, Y. 2004. 'Models of the church growth movement'. Transformation, Vol 21, no.2, 2004

Ittner, C.D \& Larcker, D.F., 2003. Coming up Short on Non-financial Performance Measurement. Harvard Business Review, November, pp. 1-9 
Levin, R. I. and Rubin, D. S. (2000) Statistics for Management, Prentice Hall of India, New Delhi

Lorange, P. Morton, M.F.S and Ghoshal, S. (1986). Strategic Control Systems (West Series in Strategic Management)

Malphurs A., 2004. Planting Growing Churches for the 21st Century, 3rd ed. (Grand Rapids: Baker, 2004), 1112

Malphurs, A., 2013. Advanced Strategic Planning. A $21^{\text {st }}$ Century Model for Church and Ministry Leaders, $3^{r d}$ Edition, Baker Books

Pearce, J. and Robinson, R. (2005). Strategic Management, 11 ed. New York: Mc Graw Hill Pearson Education, Inc., publishing as Prentice Hall, One Lake Street, Upper Saddle River, New Jersey 07458

Porter, M., 1985. Competitive Advantage. New York: Free Press

Rainer, T. S., 1993. The Book of Church Growth: History, Theology, and Principles. Nashville, TN: Broadman \& Holman Publishers, 1993

Rossouw, D., Le Roux, S.J. \& Groenewald, D. (2003). Strategic management: South African perspective including the balanced scorecard. Cape Town: New Africa Books

Shah, A. J., David, F. R., \& Surawski, Z. J., 2003. Does Strategic Planning Help Churches? An Exploratory Study. Coastal Business Journal Volume 2, 28-35

Strydon, J. 2011. Principles of Business Management. 2nd ed. Cape Town: Oxford University Press.

Toit, M., 2005. Using Environmental Scanning to Collect Strategic Information. International Journal of Information Management, 36, 16-24

Wambugu, W. C. \& Waiganjo, E. W. (2015). Effects of strategic management practices on organizational performance of construction companies in Nairobi City County, Kenya. International Academic Journal of Human Resource and Business Administration, 1 (4), 41-51

Wheelen, T. L. \& Hunger, J. D. 2003. Concepts in Strategic Management and Business Policy: Pearson Education

Widener, S.R., 2007. An empirical analysis of the levers of control framework. Accounting, Organizations and Society, 32 (7-8), pp. 757-788

Zimbabwe National Statistics Agency and ICF International. 2016. Zimbabwe Demographic and Health Survey 2015: Final Report. Rockville, Maryland, USA: Zimbabwe National Statistics Agency (ZIMSTAT) and ICF International. 